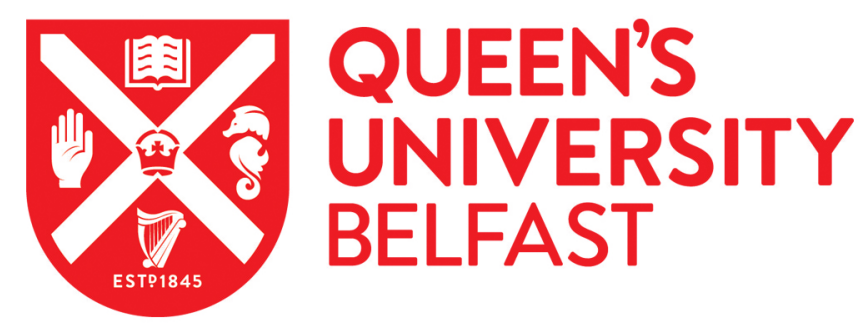

\title{
Leisure time physical activity and regular walking or cycling to work are associated with adiposity and 5 y weight gain in middle aged men the PRIME study
}

Wagner, A., Simon, C., Ducimetiere, P., Montaye, M., Bongard, V., Yarnell, J., Bingham, A., Hedelin, G., Amouyel, P., Ferrieres, J., Evans, A., \& Arveiler, D. (2001). Leisure time physical activity and regular walking or cycling to work are associated with adiposity and 5 y weight gain in middle aged men the PRIME study. International Journal of Obesity, 25(7), 940-948.

\section{Published in:}

International Journal of Obesity

Queen's University Belfast - Research Portal:

Link to publication record in Queen's University Belfast Research Portal

\section{General rights}

Copyright for the publications made accessible via the Queen's University Belfast Research Portal is retained by the author(s) and / or other copyright owners and it is a condition of accessing these publications that users recognise and abide by the legal requirements associated with these rights.

Take down policy

The Research Portal is Queen's institutional repository that provides access to Queen's research output. Every effort has been made to ensure that content in the Research Portal does not infringe any person's rights, or applicable UK laws. If you discover content in the Research Portal that you believe breaches copyright or violates any law, please contact openaccess@qub.ac.uk. 


\title{
Leisure-time physical activity and regular walking or cycling to work are associated with adiposity and $5 y$ weight gain in middle-aged men: the PRIME Study
}

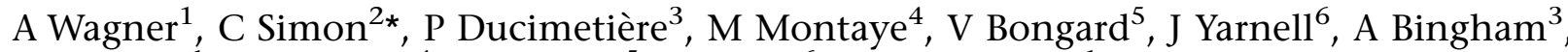 \\ G Hedelin $^{1}$, P Amouyel ${ }^{4}$, J Ferrières ${ }^{5}$, A Evans ${ }^{6}$ and D Arveiler ${ }^{1 \dagger}$
}

\begin{abstract}
${ }^{1}$ Laboratoire d'Epidémiologie et de Santé Publique, Faculté de Médecine, Strasbourg, France ${ }^{2}$ Groupe d'Etudes et de Recherche en Nutrition, Hôpitaux Universitaires, Strasbourg, France; ${ }^{3}$ INSERM U258, Hôpital Paul Brousse, Villejuif, France; ${ }^{4}$ INSERM U508, Institut Pasteur, Lille, France; ${ }^{5}$ INSERM U518, Département d'Epidémiologie, Faculté de Médecine, Toulouse, France; and ${ }^{6}$ Department of Epidemiology and Public Health, The Queen's University of Belfast, Belfast, Northern Ireland, UK
\end{abstract}

OBJECTIVE: To examine the influence of physical activity on body mass index (BMI), waist circumference (W) and body mass changes $(\triangle \mathrm{BMI})$ in middle-aged men, with special regard to moderate-intensity activities.

DESIGN: Longitudinal study of adults who participated in the PRIME Study.

SUBJECTS: A cohort of 8865 men aged 50-59y, free of coronary heart disease.

MEASUREMENTS: BMI and $\mathrm{W}$ at baseline, body mass changes over a $5 \mathrm{y}$ period. Detailed baseline assessment of net energy expenditure due to physical activity (PAE) in the preceding year, according to category of activity, by means of the MOSPA Questionnaire. PAE was expressed in weekly metabolic equivalent scores (MET h/week).

RESULTS: After adjustment for confounders, the multiple regression analyses indicated that $\mathrm{BMI}, \mathrm{W}$ and $\triangle \mathrm{BMI}$ were inversely associated with PAE spent in getting to work $\left(P<10^{-5},<10^{-5}\right.$ and 0.04 , respectively) and practice of high-intensity $(\geq 6$ MET) recreational activities $\left(<0.01,<10^{-5}\right.$ and $\left.<0.01\right)$. Men who regularly spent more than $10 \mathrm{MET} \mathrm{h} /$ week in walking or cycling to work had a mean BMI, W and $\triangle B M I$ respectively $0.3 \mathrm{~kg} / \mathrm{m}^{2}, 1 \mathrm{~cm}$ and $0.06 \mathrm{~kg} / \mathrm{m}^{2}$ lower than those who did not expend energy in getting to work. In the subgroup of subjects who did not perform high-intensity activities, the level of recreational PAE was inversely associated with BMI and $\mathrm{W}$ but not with subsequent weight-gain.

CONCLUSION: These findings indicate that, in middle-aged men, physical activities of moderate-intensity, which are probably easier to promote than more vigorous activities and, in particular, a more current daily activity, walking or cycling to work, may have a favourable effect on body fat markers and body mass gain.

International Journal of Obesity (2001) 25, 940-948

Keywords: physical activity; body mass index; waist circumference; body mass gain; middle-aged men; cohort study

\section{Introduction}

Several prospective studies indicate that regular exercise is associated with a decreased risk of premature death and cardiovascular disease. ${ }^{1,2}$ This association is thought to be partly related to improvement in fitness and in different cardiovascular risk factors including lipid profile, blood pressure, insulin resistance and diabetes, and haemostasis. ${ }^{3}$

*Correspondence: C Simon, Service de Médecine Interne et de Nutrition, Hôpital de Hautepierre, 67098 Strasbourg Cedex, France.

E-mail: chantal.simon@medecine.u-strasbg.fr

On Behalf of the PRIME Study Group.

Received 29 September 2000; revised 17 November 2000;

accepted 13 December 2000
In contrast, some controversy exists about the relationship between physical activity and obesity or body fat distribution, both being also significant risk factors for diabetes and coronary heart disease.

Short-term intervention studies suggest that exercise training of various intensities is a major strategy for weight control. $^{4,5}$ Similarly, cross-sectional studies consistently report lower body weight among people with higher reported physical activity. ${ }^{3,6}$ However, prospective observational population-based studies are scarce and the results somewhat confusing. An inverse association between physical activity and subsequent weight gain is suggested by several studies, ${ }^{6}$ especially for activities of high intensity. 
However, the impact of activities of low or moderate intensity, probably easier to promote, is less well established. The new physical activity recommendations for improving health have underlined the importance of moderate intensity activities practised on a regular basis. ${ }^{7}$ However, concerning weight control, the question as to whether a minimum exercise intensity is required in order to maintain weight and body composition remains open. Some experimental data indicate that high-intensity activity may confer substantial benefits for weight control, ${ }^{8}$ but it is unclear whether the intensity of the physical activities instead of the total energy expended is important in maintaining weight $\operatorname{loss}^{9}$ or preventing weight gain in free-living subjects.

The purpose of this study was to investigate at a population level, the relationship between physical activity and body weight, body fat distribution and $5 \mathrm{y}$ weight gain, with special regard to regular walking or cycling to work and to activities of moderate intensity. We analysed data from The Prospective Epidemiological Study of Myocardial Infarction (The PRIME Study), a prospective study conducted in a large cohort of 50 to 59 -y-old men free of coronary heart disease. ${ }^{10}$ Since fat accumulates with increasing age, better knowledge of physical activity patterns and their associations with body fat markers at this age may have public health implications.

Physical activity was evaluated by means of the MONICA (MONItoring of trends and determinants in CArdiovascular disease) Optional Study of Physical Activity Questionnaire (MOSPA-Q), a questionnaire developed by the Center for Disease Control and Prevention (CDC) and the World Health Organization (WHO) in an attempt to estimate the usual physical activity amount and pattern of the individual. ${ }^{11}$ This questionnaire measures the usual time and energy expended in different activities: sport, but also other leisure-time, occupational and more daily ones such as means of getting to work over the past year.

\section{Methods \\ Sample}

The PRIME Study is a prospective study conducted in a cohort of 50 to 59-y-old men, which was established in order to evaluate the contribution of risk and genetic factors to the development of coronary heart disease. It has arisen from the World Health Organization MONICA Project collaboration and is based on the three French Centres (the department of Bas-Rhin (STR) in the East, the urban community of Lille (LIL) in the North, the department of HauteGaronne (TOU) in the South), and the Northern Irish Centre (Belfast (BEL)). Detailed information about the aims and methods has been described elsewhere. ${ }^{10}$ Recruitment began in 1991 and was completed in 1993 in all centres. The sample was recruited to broadly match the social class structure of the background population and to represent 5$8 \%$ of the total 50 to 59 -y-old male population of each centre; 10600 men equally distributed between each centre were finally recruited. Participation was voluntary and a formal consent form was signed by the subjects. Each study centre obtained local approval from the appropriate ethical committee. After exclusion of 842 men who had a history or clinical signs of coronary heart disease and of those who died or presented with a diagnosis of cancer during the 5-y followup, a total of 8865 men constituted the final sample. There were 796 men for whom weight during follow-up was missing who were further excluded from the analyses of weight change. Analysis of anthropometric, lifestyle and socio-economical baseline data indicated that they did not differ significantly from the other subjects.

\section{Study design}

Subjects were initially given a morning appointment for questionnaire administration (health, lifestyle, socio-economic and physical activity data), physical and anthropometric examination, and blood sampling; they were then contacted annually by means of a letter or by telephone and asked about health events, current weight and changes in smoking status or employment status.

\section{Lifestyle and socio-economic data}

Educational level was classified into three categories (primary school; secondary school or technical training; university). Smoking status was defined by questions on present and past consumption. Smokers were defined as individuals currently smoking at least one cigarette per day. Alcohol consumption was assessed by a quantitative frequency questionnaire as previously described. ${ }^{12}$ Subjects were classified into three groups: teetotallers; consuming less than $30 \mathrm{~g}$ of alcohol per day; and consuming $30 \mathrm{~g}$ per day or more. Centre, age group $(<55 \mathrm{y}, \geq 55 \mathrm{y})$, marital status (never married; married; divorced, separated or widowed), pursuit of weight-control diet (yes or no), socio-occupational class (three classes), current employment status (yes or no) were also considered as well as changes in employment and smoking status during follow-up.

\section{Assessment of physical activity}

The MOSPA-Q was used to assess the amount of physical activity performed during the previous year, according to the category of physical activity (occupational activity, walking or cycling to and from work and leisure-time activities). Briefly, this questionnaire described in detail elsewhere, ${ }^{11}$ whose validation and reliability have been reported, ${ }^{13}$ was administered by a trained interviewer in order to assess the time and mean energy expenditure spent on physical activity at work, during transportation to and from work, and during leisure-time. Subjects were instructed to make clear distinctions between each category of physical activity to avoid possible overlap. They were asked about time spent sitting, standing, walking, lifting or carrying objects of varying weight at work during a typical day. Time spent in 
walking or cycling to work was recorded. For leisure-time activities, walking and the two physical activities that were most frequently performed (sport, exercise or others, such as gardening, etc) during the previous year were taken into account. The intensities of the different activities reported were derived from the Compendium of Physical Activities ${ }^{14}$ and expressed in MET values by reference to the resting metabolic rate ( 1 MET or approximately $1 \mathrm{kcal} / \mathrm{kg} / \mathrm{h}$ ). Persons reporting no physical activity expend energy with a MET value of approximately 1 ; therefore, as previously proposed, ${ }^{15}$ we subtracted 1 from each given MET value to calculate net energy expenditure indices. The average weekly net energy expenditure due to physical activity, expressed in MET $\mathrm{h} /$ week, was computed for different activities as the sum of time spent on the activity items multiplied by the corresponding MET values minus 1:

$$
\begin{aligned}
\text { Net energy expenditure }= & \Sigma\left(\left(\text { intensity }_{i}-1\right)\right. \\
& \left.\times \text { frequency }_{i} \times \text { duration }_{i}\right)
\end{aligned}
$$

where intensity is the energy cost of the activity $i$ in MET, frequency the weekly average number of occasions of this activity during the past year and duration its average duration in hours.

The PAE attributable to occupational activity, walking or cycling to work and leisure-time activities were computed. The subjects who did not work $(n=1741)$ were considered as having a PAE attributable to occupational activity and to walking or cycling to work equal to zero. For leisure-time activities, subjects were classified in three groups according to the average PAE expended on one week of the past year, with cut-off points of 3 and 9 MET h/week. This last cut-off point corresponds approximately to the weekly amount of energy expenditure of the American College of Sports Medicine (ACSM) and CDC recommendations. Participants were also categorised as to whether or not they performed high-intensity leisure-time activities ( $\geq 6$ MET) regularly or not.

\section{Anthropometric measurements}

Anthropometric measurements included height (to the nearest $1 \mathrm{~cm}$ ), body weight (to the nearest even decimal), and waist (to the nearest $0.5 \mathrm{~cm}$ ). The measures were taken on subjects in light clothing without shoes, with an electronic scale periodically calibrated for weight and a wall mounted rule for height. Measurement of waist circumference (W) was recorded horizontally midway between the lateral lower rib margin and iliac crest on a standing subject, after a moderate expiration. All the measure procedures were standardised between study centres and in each centre interviewers were regularly trained to perform these measurements according to the standard protocol. Body mass index (BMI) was computed as weight $(\mathrm{kg})$ divided by height squared $\left(\mathrm{m}^{2}\right)$. Body weight change during the $5 \mathrm{y}$ follow-up was computed as body weight reported by the subjects after $5 \mathrm{y}$ of follow-up less the body weight recorded at the initial visit. Variation in BMI was considered.

\section{Statistical analysis}

Statistical analyses were performed using the BMDP Statistical Software. ${ }^{16}$ Univariate statistics (means and frequencies) were computed for all dependent variables and variables of interest as well as for behavioural, demographic and potential confounders. Comparisons were made using the chisquare test for categorical variables and one-way ANOVA for continuous variables.

Multiple linear regression models were fitted to assess the independent association of PAE due to walking or cycling to work, PAE due to leisure-time activities and high-intensity recreational activities with BMI, waist circumference and body mass changes $(\triangle \mathrm{BMI})$. Product terms were used in the analyses to evaluate a possible heterogeneity of the associations across levels of other factors. In particular, interactions between the different categories of physical activities and a two-way interaction between leisure-time PAE (in three classes of PAE level) and regular high-intensity activities (yes or no) were first considered in each model. Only the pertinent models are presented here. In order to investigate the influence of activities of moderate intensity in depth, the same analyses were secondarily performed in the subgroup of subjects who did not regularly practise high-intensity $(\geq 6$ MET) recreational activities. All these analyses were performed after controlling for several potential confounding factors including centre, age, marital status, educational level, socio-occupational class, pursuit of weight control diet, alcohol and smoking habits and PAE at work. Initial BMI and changes in employment and smoking status were also taken into account in predicting BMI change. Both 3 and $5 \mathrm{y}$ follow-up data were analysed; only the $5 \mathrm{y}$ results are detailed here.

\section{Results}

\section{Baseline characteristics}

Demographic, behavioural and anthropometric characteristics of the 8865 subjects are detailed in Table 1. Participants averaged $54.9 \pm 2.9 \mathrm{y}$, had predominantly received secondary or technical education, were married, and had a current occupational activity. About $15 \%$ were obese (BMI $\geq$ $30 \mathrm{~kg} / \mathrm{m}^{2}$ ) and $21.5 \%$ had a high-risk waist circumference (W $\geq 102 \mathrm{~cm}$ ). Prevalence of obesity and of high waist circumference was lower in Belfast than in the three French centres $\left(P<10^{-4}\right)$.

Complete data on 8069 subjects were available for the longitudinal analysis. On average, participants gained $0.22 \pm 4.45 \mathrm{~kg}$, which corresponded to a $\Delta \mathrm{BMI}$ of $0.07 \pm$ $1.49 \mathrm{~kg} / \mathrm{m}^{2}$ with a great range of change $(-26$ to $+40 \mathrm{~kg})$; $8.3 \%$ of the sample lost more than $5 \mathrm{~kg}$ whereas $9.5 \%$ gained more than $5 \mathrm{~kg}$ during the $5 \mathrm{y}$ period. Smoking cessation was noted in $8 \%$ of the subjects (nearly one-third of the baseline smokers) and $46 \%$ retired during follow-up. 
Table 1 Selected demographic, behavioural and anthropometric characteristics of participants at baseline

\begin{tabular}{|c|c|}
\hline Characteristic & $\mathrm{n}=8865$ \\
\hline Age $(y ;$ mean \pm s.d. $)$ & $54.9 \pm 2.9$ \\
\hline \multicolumn{2}{|l|}{ Education (\%) } \\
\hline Primary & 25.0 \\
\hline Secondary or technical & 59.4 \\
\hline University & 15.6 \\
\hline \multicolumn{2}{|l|}{ Marital status (\%) } \\
\hline Never married & 4.7 \\
\hline Married & 88.1 \\
\hline Divorced/separated/widowed & 7.2 \\
\hline Employed (\%) & 80.4 \\
\hline \multicolumn{2}{|l|}{ Socio-professional category (\%) } \\
\hline Low & 17.6 \\
\hline Medium & 53.1 \\
\hline High & 29.3 \\
\hline Currently weight-control diet (\%) & 7.3 \\
\hline \multicolumn{2}{|l|}{ Alcohol $(\%)$} \\
\hline Teetotallers & 16.0 \\
\hline$<30$ g per day & 43.6 \\
\hline$\geq 30 \mathrm{~g}$ per day & 40.4 \\
\hline \multicolumn{2}{|l|}{ Smoking (\%) } \\
\hline Never smokers & 30.1 \\
\hline Former smokers & 43.6 \\
\hline Current smokers & 26.3 \\
\hline Weight (kg; mean \pm s.d.) & $79.4 \pm 11.4$ \\
\hline Height (cm; mean \pm s.d.) & $172.8 \pm 6.5$ \\
\hline Body mass index $\left(\mathrm{kg} / \mathrm{m}^{2} ;\right.$ mean \pm s.d. $)$ & $26.6 \pm 3.4$ \\
\hline Waist $(\mathrm{cm} ;$ mean \pm s.d. $)$ & $94.6 \pm 9.9$ \\
\hline
\end{tabular}

\section{Physical activity patterns}

Table 2 illustrates the baseline mean participation in the different categories of physical activity as obtained by the MOSPA questionnaire. The mean weekly PAE at work was $63.1 \pm 43.7 \mathrm{MET} \mathrm{h} /$ week much higher than during leisure-

Table 2 Baseline physical pattern of the 8865 study participants according to the different categories of activity

\begin{tabular}{lc}
\hline Physical activity category & $\mathrm{n}=8865$ \\
\hline $\begin{array}{l}\text { Occupational activity } \\
\text { Mean PAE } \pm \text { s.d. (MET h/week) }\end{array}$ & $63.1 \pm 43.7$ \\
Walking or cycling to work & \\
Mean PAE \pm s.d. (MET h/week) & $2.3 \pm 5.5$ \\
Distribution according to PAE Levels (\%) & 65.1 \\
$\quad$ No & 24.8 \\
$\quad$ Low level (0-7 MET h/week) & 10.1 \\
$\quad$ Moderate level ( $>7$ MET h/week) & \\
Leisure time & $24.2 \pm 26.9$ \\
Mean PAE \pm s.d. (MET h/week) & 14.9 \\
Distribution according to PAE levels (\%) & 16.8 \\
$\quad$ Low level ( $\leq 3$ MET h/week) & 68.2 \\
$\quad$ Moderate level (3-9 MET h/week) & \\
$\quad$ High level (>9 MET h/week) & 32.1 \\
Distribution according to high-intensity ( $\geq 6$ MET) activities (\%) & 67.9 \\
$\quad$ Regular practice & \\
$\quad$ No practice &
\end{tabular}

${ }^{\mathrm{a}}$ Means are calculated with inclusion of the subjects who did not work (19.6\% of the subjects; PAE attributable to occupationai activity and walking or cycling to work equal to zero). time $(24.2 \pm 26.9 \mathrm{MET} \mathrm{h} /$ week $)$ or getting to work $(2.3 \pm 5.5$ MET $\mathrm{h} /$ week). Walking or cycling to work was regularly performed by $34.9 \%$ of the participants, representing $43 \%$ of the workers. Low levels of recreational PAE $(\leq 3$ MET $\mathrm{h} /$ week the equivalent of $60 \mathrm{~min}$ walking) were reported by $14.9 \%$ of the subjects, whilst $68.2 \%$ of the participants spent more than 9 MET $h$ /week during recreational physical activities. This level approximates to 30 min of brisk walking on 5 days a week as recommended for the general population. ${ }^{7}$ By contrast only about one-third of the subjects reported regular high-intensity recreational activities.

Subjects reporting regular walking or cycling to work and those who did not practised regular high-intensity recreational activities in a similar proportion. In contrast, the former were less likely to have high levels of recreational PAE $(P<0.01)$. Univariate analyses revealed that participation in occupational activities, walking or cycling to work or leisure-time activities, as well as anthropometric data, were significantly associated with different socio-demographic and lifestyle variables (Table 3). Further analyses of the relationship between physical activity and body fat markers or weight changes were adjusted for these potential confounders.

\section{Cross-sectional association between physical activity and BMI or W}

The independent association of recreational and transportrelated PAE with BMI and W was analysed by means of multiple linear regression models (Table 4). In order to evaluate the effects of the intensity of the physical activities practised whatever their energy cost, a binomial variable (regularly performing high-intensity recreational activities or not) was also considered, as well as its interaction with the energy cost of the recreational physical activities. Different interactions between the other variables were also tested for but the results did not significantly change and are not presented here. In particular, an interaction with the country of origin (France or Northern Ireland) was considered but no clear difference could be noted.

The PAE due to walking or cycling to work was strongly and negatively related to both $\mathrm{BMI}$ and $\mathrm{W}\left(P<10^{-5}\right)$. In average, subjects who reported $10 \mathrm{MET} h /$ week as cycling or walking to work, the equivalent of $30 \mathrm{~min}$ per day, had a mean BMI and a mean W respectively $0.31 \mathrm{~kg} / \mathrm{m}^{2}$ (equivalent to $950 \mathrm{~g}$ for a typical man $1.75 \mathrm{~m}$ tall) and $1 \mathrm{~cm}$ lower than those who did not regularly walk or cycle to work.

Performing high-intensity recreational activities was associated with lower BMI whatever the level of energy expended $(P<0.01)$ but a significant interaction was noted between leisure-time PAE and the practice of high-intensity activities $(P<0.04)$. Both the energy cost of the recreational activities and the regular practice of vigorous activities were negatively associated with $\mathrm{W}$, with no significant interaction (only the model without interaction is presented). The subjects who reported high recreational PAE had a mean $\mathrm{W} 0.79 \mathrm{~cm}$ lower 
Table 3 Anthropometric parameters and baseline physical activities (mean s.d.) of participants according to the demographic and behavioural characteristics

\begin{tabular}{|c|c|c|c|c|c|c|c|}
\hline & $\begin{array}{c}\text { BMI } \\
\left(\mathrm{kg} / \mathrm{m}^{2}\right)\end{array}$ & $\begin{array}{l}\text { Waist } \\
(\mathrm{cm})\end{array}$ & $\begin{array}{c}\triangle B M I \\
\left(\mathrm{~kg} / \mathrm{m}^{2}\right)\end{array}$ & $\begin{array}{c}\text { Occupational } \\
\text { activity } \\
\left(P A E^{\mathrm{a}}\right)\end{array}$ & $\begin{array}{l}\text { Walking or } \\
\text { cycling to work } \\
\left(P A E^{\mathrm{a}}\right)\end{array}$ & $\begin{array}{l}\text { Leisure-time } \\
\quad\left(P A E^{\mathrm{a}}\right)\end{array}$ & $\begin{array}{c}\text { Practice of high } \\
\text { intensity activities } \\
\text { (\%) }\end{array}$ \\
\hline \multicolumn{8}{|l|}{ Education } \\
\hline Primary & $26.94(3.66)$ & $95.61(10.49)$ & $0.19(1.73)$ & $62.85(51.94)$ & $2.22(5.81)$ & $25.42(31.34)$ & 20.0 \\
\hline Secondary or technical & $26.64(3.39)$ & $94.73(9.75)$ & $0.06(1.43)$ & $64.15(42.81)$ & $2.31(5.45)$ & $24.90(26.31)$ & 33.2 \\
\hline University & $\begin{array}{l}25.72(2.97) \\
P<10^{-4}\end{array}$ & $\begin{array}{l}92.39(8.80) \\
P<10^{-4}\end{array}$ & $\begin{array}{c}-0.02(1.33) \\
P<10^{-3}\end{array}$ & $\begin{array}{l}59.49(30.06) \\
P<10^{-2}\end{array}$ & $\begin{array}{l}2.18(5.47) \\
\text { NS }\end{array}$ & $\begin{array}{l}19.61(19.61) \\
P<10^{-4}\end{array}$ & $\begin{array}{l}47.5 \\
P<10^{-4}\end{array}$ \\
\hline \multicolumn{8}{|l|}{ Marital status } \\
\hline Never married & $26.65(4.14)$ & $94.38(10.93)$ & $0.17(1.92)$ & $57.45(47.56)$ & $3.45(7.01)$ & $19.52(24.35)$ & 26.2 \\
\hline Married & $26.57(3.32)$ & $94.60(9.66)$ & $0.07(1.45)$ & $63.82(43.27)$ & $2.22(5.47)$ & $24.58(26.88)$ & 32.6 \\
\hline Divorced/separated/widowed & $\begin{array}{l}26.56(4.04) \\
\text { NS }\end{array}$ & $\begin{array}{l}94.59(11.35) \\
\text { NS }\end{array}$ & $\begin{array}{l}0.14(1.70) \\
\text { NS }\end{array}$ & $\begin{array}{l}57.79(45.29) \\
P<10^{-3}\end{array}$ & $\begin{array}{l}2.19(5.27) \\
P<10^{-3}\end{array}$ & $\begin{array}{l}22.59(27.74) \\
P<10^{-3}\end{array}$ & $\begin{array}{l}30.1 \\
P=0.02\end{array}$ \\
\hline \multicolumn{8}{|l|}{ Employed } \\
\hline No & $26.94(3.77)$ & $96.56(10.55)$ & $0.05(1.63)$ & 0 & 0 & $37.65(40.24)$ & 28.0 \\
\hline Yes & $\begin{array}{l}26.48(3.33) \\
P<10^{-4}\end{array}$ & $\begin{array}{l}94.10(9.61) \\
P<10^{-4}\end{array}$ & $\begin{array}{l}0.08(1.46) \\
\text { NS }\end{array}$ & $78.52(34.09)$ & $2.83(6.06)$ & $\begin{array}{l}20.91(21.13) \\
P<10^{-4}\end{array}$ & $\begin{array}{l}33.1 \\
P<10^{-4}\end{array}$ \\
\hline \multicolumn{8}{|l|}{ Socio-professional category } \\
\hline High & $26.10(3.06)$ & $93.29(9.28)$ & $0.01(1.41)$ & $58.95(31.21)$ & $2.21(5.02)$ & $20.90(22.18)$ & 39.8 \\
\hline Medium & $26.77(3.46)$ & $95.23(9.79)$ & $0.08(1.47)$ & $65.50(47.88)$ & $2.04(5.20)$ & $25.91(28.46)$ & 30.7 \\
\hline Low & $\begin{array}{l}26.78(3.78) \\
P<10^{-4}\end{array}$ & $\begin{array}{l}94.87(10.70) \\
P<10^{-4}\end{array}$ & $\begin{array}{l}0.17(1.67) \\
P<10^{-2}\end{array}$ & $\begin{array}{l}62.90(47.37) \\
P<10^{-4}\end{array}$ & $\begin{array}{l}3.03(7.05) \\
P<10^{-4}\end{array}$ & $\begin{array}{l}24.79(28.50) \\
P<10^{-4}\end{array}$ & $\begin{array}{l}33.8 \\
P<10^{-4}\end{array}$ \\
\hline \multicolumn{8}{|l|}{ Currently weight-control diet } \\
\hline No & $26.43(3.34)$ & $94.22(9.70)$ & $0.06(1.47)$ & $63.65(43.78)$ & $2.31(5.61)$ & $24.20(26.81)$ & 31.8 \\
\hline Yes & $\begin{array}{l}28.32(3.95) \\
P<10^{-4}\end{array}$ & $\begin{array}{l}99.29(10.53) \\
P<10^{-4}\end{array}$ & $\begin{array}{l}0.26(1.76) \\
P<10^{-2}\end{array}$ & $\begin{array}{l}55.92(41.71) \\
P<10^{-4}\end{array}$ & $\begin{array}{l}1.80(4.56) \\
P<10^{-2}\end{array}$ & $\begin{array}{l}24.24(27.31) \\
\text { NS }\end{array}$ & $\begin{array}{l}35.2 \\
\text { NS }\end{array}$ \\
\hline \multicolumn{8}{|l|}{ Alcohol } \\
\hline Teetotallers & $26.33(3.65)$ & $92.47(10.39)$ & $0.10(1.70)$ & $60.10(40.53)$ & $2.88(6.41)$ & $20.73(23.48)$ & 24.7 \\
\hline$<30$ g per day & $26.44(3.36)$ & $94.16(9.58)$ & $0.06(1.44)$ & $62.54(40.66)$ & $2.31(5.54)$ & $23.97(25.47)$ & 36.0 \\
\hline$\geq 30$ g per day & $\begin{array}{l}26.81(3.38) \\
P<10^{-4}\end{array}$ & $\begin{array}{l}95.87(9.74) \\
P<10^{-4}\end{array}$ & $\begin{array}{l}0.08(1.47) \\
\text { NS }\end{array}$ & $\begin{array}{l}64.85(47.74) \\
P<10^{-2}\end{array}$ & $\begin{array}{l}1.99(5.15) \\
P<10^{-4}\end{array}$ & $\begin{array}{l}25.83(29.29) \\
P<10^{-4}\end{array}$ & $\begin{array}{l}30.7 \\
P<10^{-4}\end{array}$ \\
\hline \multicolumn{8}{|l|}{ Smoking } \\
\hline Never smokers & $26.33(3.24)$ & $93.38(9.43)$ & $-0.05(1.31)$ & $63.76(43.17)$ & $2.63(6.39)$ & $24.42(26.34)$ & 34.8 \\
\hline Former smokers & $26.99(3.37)$ & $95.90(9.62)$ & $0.06(1.49)$ & $61.66(42.80)$ & $2.08(5.22)$ & $25.27(27.79)$ & 33.7 \\
\hline Current smokers & $\begin{array}{l}26.15(3.62) \\
P<10^{-4}\end{array}$ & $\begin{array}{l}93.79(10.43) \\
P<10^{-4}\end{array}$ & $\begin{array}{l}0.24(1.66) \\
P<10^{-4}\end{array}$ & $\begin{array}{l}64.69(45.57) \\
P=0.02\end{array}$ & $\begin{array}{l}2.18(4.98) \\
P<10^{-3}\end{array}$ & $\begin{array}{l}22.21(25.73) \\
P=10^{-4}\end{array}$ & $\begin{array}{l}26.3 \\
P<10^{-4}\end{array}$ \\
\hline
\end{tabular}

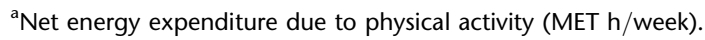

than those with low recreational PAE $(P<0.01)$. The influence of intensity of the activities was somewhat stronger $\left(P<10^{-5}\right)$ than for BMI, subjects practicing regularly one vigorous activity having $\mathrm{W}$, on average, $2 \mathrm{~cm}$ lower than those who did not.

\section{Physical activity and 5 y BMI changes}

Multiple linear regression analysis with $\triangle \mathrm{BMI}$ as dependent variable is illustrated in Table 5 . The longitudinal analyses were performed after adjustment on baseline BMI and on changes in smoking and occupational status. Regular walking or cycling to work was significantly and negatively associated with $\triangle \mathrm{BMI}(P=0.04)$, although the relationship was less strong than in the cross-sectional analyses.

Energy expended during leisure-time reported at baseline was not related to $\triangle \mathrm{BMI}$. In contrast engaging in highintensity leisure-time activities was a significant protector against weight gain $\left(P<10^{-2}\right)$; this effect was even stronger
$\left(P<10^{-4}\right)$ when $\triangle B$ MI during the first $3 \mathrm{y}$ of follow-up was considered (results not shown). Subjects who performed high-intensity leisure-time activities had a 3 and 5 y $\mathrm{BMI}$ gain, respectively 0.13 and $0.10 \mathrm{~kg} / \mathrm{m}^{2}$, lower than subjects who did not. This is equivalent to 400 and $300 \mathrm{~g}$ respectively for a typical man.

\section{Analysis of the subgroup with no high-intensity recreational activity}

In order to differentiate the effect of activities of moderate intensity, the subgroup of subjects who did not report regular practice of high-intensity activities (defined as $\geq 6 \mathrm{MET}$, for example jogging) was further analysed. Results of the three models obtained with BMI, W and $\Delta \mathrm{BMI}$ are shown in Table 6. PAE in walking or cycling to work was inversely associated with BMI or W. A negative relationship between PAE due to walking or cycling to work and $\triangle \mathrm{BMI}$ was also noted but was not significant $(P=0.07)$. Concerning recreational PAE, a 
Table 4 Cross-sectional analysis in the 8865 subjects of the PRIME cohort: multiple linear regression analyses with respective baseline BMI and waist as dependent variables ${ }^{a, b}$

\begin{tabular}{|c|c|c|c|}
\hline Variables & Coefficient & $\begin{array}{c}\text { Standard } \\
\text { error }\end{array}$ & $\mathrm{P}$ \\
\hline \multicolumn{4}{|l|}{ BMI (model $\left.r^{2}: 0.0770\right)$} \\
\hline Walking or cycling to work (MET h/week) & -0.0310 & 0.0065 & $<10^{-5}$ \\
\hline \multicolumn{4}{|l|}{ Leisure-time activity } \\
\hline Low PAE & (reference) & & \\
\hline Moderate PAE & -0.2544 & 0.1382 & 0.07 \\
\hline High PAE & -0.3036 & 0.1109 & $<0.01$ \\
\hline \multicolumn{4}{|l|}{ High-intensity leisure-time activities } \\
\hline No & (reference) & & \\
\hline Yes & -0.9755 & 0.3022 & $<0.01$ \\
\hline Interaction, moderate PAE $\times$ intensity & 0.4892 & 0.3608 & 0.18 \\
\hline Interaction, high PAE $\times$ intensity & 0.6414 & 0.3135 & 0.04 \\
\hline \multicolumn{4}{|l|}{ Waist (model $r^{2}: 0.1264$ ) } \\
\hline Walking or cycling to work (MET h/week) & -0.1027 & 0.0184 & $<10^{-5}$ \\
\hline \multicolumn{4}{|l|}{ Leisure-time activity } \\
\hline Low PAE & (reference) & & \\
\hline Moderate PAE & -0.4482 & 0.3525 & 0.19 \\
\hline High PAE & -0.7922 & 0.2904 & $<0.01$ \\
\hline \multicolumn{4}{|l|}{ High-intensity leisure-time activities } \\
\hline No & (reference) & & \\
\hline Yes & -2.0931 & 0.2239 & $<10^{-5}$ \\
\hline
\end{tabular}

${ }^{\mathrm{a}}$ Data were adjusted for centre, age group, marital status, educational level, employment status, socio-occupational class, following a weight-control diet, alcohol consumption, smoking status and occupational-related PAE.

${ }^{b}$ Levels of leisure-time activities were defined as low ( $\leq 3 \mathrm{MET} h /$ week), moderate (3-9 MET h/week) and high ( $>9$ MET h/week). Leisure-time activities were considered as high-intensity when $\geq 6 \mathrm{MET}$.

significant negative association with BMI and W but not with $\triangle \mathrm{BMI}$ was observed. Hence in contrast with the sedentary group, subjects performing more than 9 MET $\mathrm{h} /$ week of low-to-moderate intensity activities during leisuretime had mean BMIs and Ws which were $0.33 \mathrm{~kg} / \mathrm{m}^{2}$ $\left(P<10^{-2}\right)$ and $0.90 \mathrm{~cm}\left(P<10^{-2}\right)$ lower, respectively.

Table 5 Longitudinal analysis in the 8069 subjects of the PRIME cohort: multiple linear regression analysis with $\triangle B M I$ as a dependent variable ${ }^{a, b}$

\begin{tabular}{lccc}
\hline Variables (model $\mathrm{r}^{2}$ : 0.0737) & Coefficient & $\begin{array}{c}\text { Standard } \\
\text { error }\end{array}$ & $\mathrm{P}$ \\
\hline $\begin{array}{l}\text { Walking or cycling to work } \\
\quad \text { MET h/week) }\end{array}$ & -0.0059 & 0.0029 & 0.04 \\
$\begin{array}{l}\text { Leisure-time activity } \\
\text { Low PAE }\end{array}$ & & & \\
$\quad$ Moderate PAE & (reference) & & 0.50 \\
$\quad$ High PAE & -0.0380 & 0.0580 & 0.50 \\
High-intensity leisure-time activities & -0.0186 & 0.0478 & \\
$\quad$ No & & & \\
$\quad$ Yes & (reference) & & \\
\hline
\end{tabular}

${ }^{a}$ Data were adjusted for centre, age group, marital status, educational level, employment status, socio-occupational class, following a weight-control diet, alcohol consumption, smoking status and occupational-related PAE, baseline body mass index and changes in smoking as well as employment status during follow-up.

${ }^{b}$ Levels of leisure-time activities were defined as low ( $\leq 3$ MET h/week), moderate (3-9 MET h/week) and high ( $>9$ MET h/week). Leisure-time activities were considered as high-intensity when $\geq 6 \mathrm{MET}$.
Table 6 Multiple linear regression analyses in the subgroup of subjects who did not regularly perform vigorous ( $\geq 6 \mathrm{MET}$ ) recreational activities with baseline BMI $(n=5990)$, baseline $\mathrm{W}(n=5990)$ and $\Delta \mathrm{BMI}$ $(n=5378)$ as dependent variables ${ }^{a}$

\begin{tabular}{|c|c|c|c|}
\hline Variables & Coefficient & $\begin{array}{c}\text { Standard } \\
\text { error }\end{array}$ & $P$ \\
\hline \multicolumn{4}{|l|}{$\mathrm{BMI}^{\mathrm{b}}\left(\right.$ model $\left.\mathrm{r}^{2}: 0.0752\right)$} \\
\hline Walking or cycling to work (MET h/week) & -0.0312 & 0.0089 & $<0.001$ \\
\hline \multicolumn{4}{|l|}{ Leisure-time activity } \\
\hline Low PAE & (reference) & & \\
\hline Moderate PAE & -0.2522 & 0.1449 & 0.09 \\
\hline High PAE & -0.3265 & 0.1166 & $<0.01$ \\
\hline \multicolumn{4}{|l|}{ Waist $^{\mathrm{b}}\left(\right.$ model $\left.r^{2}: 0.1250\right)$} \\
\hline Walking or cycling to work (MET h/week) & -0.0884 & 0.0245 & $<0.001$ \\
\hline \multicolumn{4}{|l|}{ Leisure-time activity } \\
\hline Low PAE & (reference) & & \\
\hline Moderate PAE & -0.7502 & 0.4004 & 0.09 \\
\hline High PAE & -0.9030 & 0.3221 & $<0.01$ \\
\hline \multicolumn{4}{|l|}{$\Delta B M I^{\mathrm{b}, \mathrm{c}}\left(\right.$ model $\left.\mathrm{r}^{2}: 0.0737\right)$} \\
\hline Walking or cycling to work (MET h/week) & -0.0075 & 0.0041 & 0.07 \\
\hline \multicolumn{4}{|l|}{ Leisure-time activity } \\
\hline Low PAE & (reference) & & \\
\hline Moderate PAE & -0.0564 & 0.0680 & 0.70 \\
\hline High PAE & -0.0303 & 0.0545 & 0.70 \\
\hline
\end{tabular}

${ }^{a}$ Levels of leisure-time activities were defined as low ( $\leq 3 \mathrm{MET} h /$ week), moderate (3-9 MET h/week) and high ( $>9$ MET h/week). Recreational activities were considered as high-intensity when $>6 \mathrm{MET}$.

${ }^{b}$ Data were adjusted for centre, age group, marital status, educational level, employment status, socio-occupational class, following a weight-control diet, alcohol consumption, smoking status and PAE at work.

${ }^{c}$ Data were further adjusted for baseline body mass index and changes in smoking as well as employment status during follow-up.

\section{Discussion}

This longitudinal study, conducted in a large cohort of middle-aged men, demonstrates that walking or cycling to work, a physical activity of moderate intensity but practiced on a regular basis, is inversely associated with BMI, W and $\triangle \mathrm{BMI}$ over the subsequent $5 \mathrm{y}$ period. A significant negative relationship was also found between the baseline energy expended during leisure-time and $\mathrm{BMI}$ or $\mathrm{W}$ but not $\Delta \mathrm{BMI}$ during follow-up. In contrast, regular practice of high-intensity activities during leisure-time showed a strong inverse relationship with body fat markers both in the crosssectional and longitudinal analyses.

An important finding of this study was the negative independent relationship observed between energy expended during walking or cycling to work and subsequent weight changes. Our results also showed that, even in the absence of high-intensity activities, the energy expended during leisure-time is inversely associated with BMI and W. These observational results do not establish a causal relationship. Nevertheless, they support the hypothesis that even low-tomoderate intensity physical activities, feasible by most adults, are beneficial for preventing weight gain with age. Several large-scale observational studies indicate a relationship between baseline or improvement in physical activity ${ }^{17-23}$ or cardiorespiratory fitness ${ }^{24,25}$ and subsequent weight gain or risk of becoming overweight. As in our cohort, regular performing of high-intensity activity during leisure-time was 
generally a strong predictor of subsequent weight changes. However, we are not aware of prospective population-based studies that specifically assessed the role of walking or cycling to work on weight changes during follow-up and only a few studies have assessed the influence of low-to-moderate intensity physical activities. These studies conducted in 20-50 aged adults gave inconsistent results. French et al ${ }^{18}$ found that changes in moderate-intensity activities was inversely associated with $2 \mathrm{y}$ weight changes in both men and women. In contrast, two other small cohort studies ${ }^{20,26}$ reported a beneficial effect of these activities in women but not in men. Our results were obtained in men aged from 50-59y at baseline, an age group that is, as women are, less likely to practice high-intensity activities and this may have contributed to the detection of the benefits of lower intensity recreational activities.

Several reasons may explain the lack of relationship between the energy expended during leisure-time, independently of performing high-intensity activities, and subsequent weight gain, which contrasts with the influence of walking or cycling to work. Misclassification, due to a less accurate reporting of some recreational activities, in particular those that are less vigorous or less structured, is possible. In fact, the reproducibility of the MOSPA-Q has been shown to be higher for vigorous activities, such as sports activities, compared to non-vigorous ones. ${ }^{13}$ Similarly, respondents may more accurately recall regular walking or cycling to work, which is a more structured activity, performed on a daily basis. This last activity may also be less prone to change over time and its regularity is probably determinant; frequency of walking, for leisure or other, was found to be associated with lower weight among subjects aged $40 \mathrm{y}$ or more trying to lose weight. ${ }^{27}$ In two of the studies reporting the influence of moderate-intensity recreational activities, ${ }^{18,26}$ the frequency rather than the total amount of these activities was studied. Through our questionnaire, the global frequency of the recreational activities could not accurately be estimated, so that the influence of their regularity could not be determined. More generally, since body composition is known to change with age and BMI does not distinguish fat from fat-free mass, the use of $\Delta \mathrm{BMI}$ may also explain the weaker results of the longitudinal analyses. $^{28,29}$

The strengths of our study were assessment of physical activity for the previous 12 months, a period that includes seasonal variations on physical activity choice ${ }^{30}$ and adjusting for several confounding socio-demographic, lifestyle factors and occupational physical activity. The importance of adjusting for occupational activity, which represents the greater part of the daily physical activity expenditure, has been recently emphasised. ${ }^{29}$ Use of $\mathrm{W}$, which is well related to central abdominal fat mass, ${ }^{31}$ in addition to BMI, has also contributed to assess the relationship between physical activity and adiposity.

Some limitations of our study should be considered and could explain the weaker relationship between baseline level of physical activity and subsequent weight gain. Unfortu- nately, change in $\mathrm{W}$ could not be calculated since $\mathrm{W}$ was not asked for at follow-up. We were unable to take into account changes in physical activity, which may have occurred over time, although work cessation was considered. In fact, in two recent prospective studies, one-third to one-half of the subjects changed their leisure-time activity during the $10 \mathrm{y}$ follow-up. ${ }^{20,22}$ Also only two physical activities and walking were included in the assessment of leisure-time physical activity. We cannot exclude the possibility that this may have lead to an underestimation of the intensity level of physical activity since more intense activities may be performed as the third most frequent. However it should be noted that more than $65 \%$ of the subjects reported no or only one physical activity. On the other hand, we did not control for food intake and could not account for the influence of energy intake on the relationship between physical activity and weight or body composition; however, dieting efforts, which have been shown to be strongly related to subsequent weight gain, ${ }^{18,23}$ and alcohol consumption have been studied. Moreover whereas baseline BMI was obtained from a standardised measure of weight and height, only reported weight was available during followup. Therefore, we cannot exclude some reported errors among various subgroups, but various studies, that compared measured and self-reported weight, showed that men were less likely to underestimate their weight than women. ${ }^{32,33}$ Although the magnitude of the associations found between moderate-intensity leisure-time activity and weight can be thought to be small, they may have health implications at a population level taking into account a cumulative effect over years and the increasing prevalence of obesity in most western countries. ${ }^{34}$

In summary, these data from a large cohort of European middle-aged men indicate that low-to-moderate intensity activities - recreational or as a more current daily activity, walking or cycling to work - may favourably influence body fat markers and also $5 \mathrm{y} \Delta \mathrm{BMI}$. Further studies are required to establish whether the differences found between recreational activities and walking or cycling to work are due to a less accurate evaluation of the recreational activities or to the regularity of the work-related transportation. Use of more precise measurements of daily activities, such as those obtained with accelerometers for example, could help to detect the real impact of physical activity frequency or regularity, which may also depend on sex and age. Nevertheless, these results support guidelines that endorse moderate-intensity physical activities, which are safe, achievable by most adults, and probably easier to maintain on a long-term basis. In the same way, it has been shown that brisk walking and vigorous exercise are associated with similar reductions in the incidence of coronary events in women. ${ }^{35}$

\section{Acknowledgements}

We thank the following organisations which allowed the recruitment of the PRIME subjects: the Health Screening 
Centre organised by the Social Security of Lille (Institut Pasteur), Strasbourg, Toulouse and Tourcoing; Occupational Medicine Services of Haute Garonne, of the Urban Community of Strasbourg, the Association Inter-entreprises des services médicaux du travail de Lille et environs, the Comité pour le développement de la médecine du travail; the Mutuelle Générale des PTT du Bas-Rhin, the Department of Health and Social Services, Northern Ireland and the Northern Ireland Chest Heart and Stroke Association. The PRIME Study is organised under an agreement between INSERM and the Merck, Sharpe and Dohme-Chibret laboratory, with the following participating laboratories: the Strasbourg MONICA Project, Department of Epidemiology and Public Health, Faculty of Medicine, Strasbourg, France (D Arveiler, B Haas); the Toulouse MONICA Project, INSERM U518, Department of Epidemiology, Paul Sabatier, Toulouse Purpan University, France (J Ferrières, JB Ruidavets); the Lille MONICA Project, INSERM U508, Pasteur Institute, Lille, France (P Amouyel, M Montaye), the Departments of Epidemiology and Public Health, Medicine and Psychology, the Queen's University of Belfast, Belfast, Northern Ireland (A Evans, J Yarnell, D McMaster, D Sykes); the Department of Atherosclerosis, SERLIA-INSERM U325, Lille, France (G Luc, JM Bard, JC Fruchart); the Laboratory of Haematology, La Timone Hospital, Marseilles, France (I Juhan-Vague); the Laboratory of Endocrinology, INSERM U326, Toulouse, France (B Perret); the Vitamin Research Unit, The University of Bern, Bern, Switzerland (F Gey); the DNA Bank, INSERM U525/SC7, Paris, France (F Cambien); the Coordinating Centre, INSERM U258, Paris, France (P Ducimetière, PY Scarabin, A Bingham).

\section{References}

1 Berlin JA, Colditz GA. A meta-analysis of physical activity in the prevention of coronary heart disease. Am J Epidemiol 1990; 132: 612-628.

2 Paffenbarger RS Jr, Hyde RT, Wing AL, Lee IM, Jung DL, Kampert JB. The association of changes in physical-activity level and other lifestyle characteristics with mortality among men. New Engl J Med 1993; 328: 538-545.

3 Department of Health and Human Services. Physical Activity and Health: a report of the Surgeon General. Centers for Disease Control and Prevention: Atlanta, National Center for Chronic Disease Prevention and Health Promotion GA; 1996.

4 McGuire MT, Wing RR, Klem ML, Hill JO. Behavioral strategies of individuals who have maintained long-term weight losses. Obes Res 1999; 7: 334-341.

5 Ballor DL, Keesey RE. A meta-analysis of the factors affecting exercise-induced changes in body mass, fat mass and fat-free mass in males and females. Int J Obes 1991; 15: 717-726.

6 DiPietro L. Physical activity in the prevention of obesity: current evidence and research issues. Med SciSports Exerc 1999; 31:S542-S546.

7 Pate RR, Pratt M, Blair SN, Haskell WL, Macera CA, Bouchard C, Buchner D, Ettinger W, Heath GW, King AC, Kriska A, Leon AS, Marcus BH, Morris J, Paffenbarger RS Jr, Patrick K, Pollock ML, Rippe JM, Sallis J, Wilmore JH. Physical activity and public health: a recommendation from the Centers for Disease Control and Prevention and the American College of Sports Medicine. JAMA 1995; 273: 402-407.
8 Tremblay A, Després JP, Leblanc C, Craig CL, Ferris B, Stephens T, Bouchard C. Effect of intensity of physical activity on body fatness and fat distribution. Am J Clin Nutr 1990; 51: 153-157.

9 Wing RR. Physical activity in the treatment of the adulthood overweight and obesity: current evidence and research issues. Med Sci Sports Exerc 1999; 31: S547-S552.

10 The PRIME Study Group (prepared by Yarnell JWG). The PRIME Study: classical risk factors do not explain the severalfold differences in risk of coronary heart disease between France and Northern Ireland. Q J Med 1998; 91: 667-676.

11 Pereira MA, Fitzgerald SJ, Gregg EW, Joswiak ML, Ryan WJ, Suminski RR, Utter AC, Zmuda JM. A collection of physical activity questionnaires for health-related research: the MONICA Optional Study of Physical Activity (MOSPA). Med Sci Sports Exerc 1997; 29: S162-S169.

12 Dallongeville J, Marécaux N, Ducimetière $\mathrm{P}$, Ferrières J, Arveiler D, Bingham A, Ruidavets JB, Simon C, Amouyel P. Influence of alcohol consumption and various beverages on waist girth and waist-to-hip ratio in a sample of French men and women. Int J Obes Relat Metab Disord 1998; 22: 1178-1183.

13 Roeykens J, Rogers R, Meeusen R, Magnus L, Borms J, de Meirleir K. Validity and reliability in a Flemish population of the WHOMONICA Optional Study of Physical Activity Questionnaire. Med Sci Sports Exerc 1998; 30: 1071-1075.

14 Ainsworth BE, Haskell WL, Leon AS, Jacobs DR Jr, Montoye HJ, Sallis JF, Paffenbarger RS Jr. Compendium of physical activities: classification of energy costs of human physical activities. Med Sci Sports Exerc 1993; 25: 71-80.

15 Haapanen N, Miilunpalo S, Pasanen M, Oja P, Vuori I. Association between leisure-time physical activity and 10-year body mass change among working-aged men and women. Int J Obes Relat Metab Disord 1997; 21: 288-296.

16 BMDP Statistical Software Inc. BMDP Statistical Software Manual, edition. University of California Press: Berkeley, CA; 1990.

17 Rissanen A, Heliovaara M, Knekt P, Reunanen A, Aromaa A. Determinants of weight gain and overweight in adult Finns. Eur I Clin Nutr 1991; 45: 419-430.

18 French SA, Jeffery RW, Forster JL, McGovern PG, Kelder SH, Baxter JE. Predictors of weight change over two years among a population of working adults: the Healthy Worker Project. Int J Obes Relat Metab Disord 1994; 18: 145-154.

19 Paeratakul S, Popkin BM, Keyou G, Adair LS, Stevens J. Changes in diet and physical activity affect the body mass index of Chinese adults. Int J Obes Relat Metab Disord 1998; 22 424-431.

20 Klesges RC, Klesges LM, Haddock CK, Eck LH. A longitudinal analysis of the impact of dietary intake and physical activity on weight change in adults. Am J Clin Nutr 1992; 55: 818-822.

21 Ching PLYH , Willett WC, Rimm EB, Colditz GA, Gortmaker SL, Stampfer MJ. Activity level and risk of overweight in male health professionals. Am J Public Health 1996; 86: 25-30.

22 Williamson DF, Madans J, Anda RF, Kleinman JC, Kahn HS, Byers T. Recreational physical activity and ten-year weight change in a US national cohort. Int J Obes Relat Metab Disord 1993; 17: 279-286.

23 Coakley EH, Rimm EB, Colditz G, Kawachi I, Willett W. Predictors of weight change in men: results from the Health Professionals Follow-up Study. Int $J$ Obes Relat Metab Disord 1998; 22: 89-96.

24 Lewis CE, Smith BE, Wallace OD, Williams OD, Bild D, Jacobs DR Jr. Seven year trends in body weight and associations of weight change with lifestyle and behavioral characteristics in black and white young adults: the CARDIA Study. Am J Public Health 1997; 87: 635-642.

25 DiPietro L, Kohl HW, Barlow CE, Blair SN. Improvements in cardiorespiratory fitness attenuate age-related weight gain in healthy men and women: the Aerobics Center Longitudinal Study. Int J Obes Relat Metab Disord 1998; 22: 55-62.

26 Sherwood NE, Jeffery RW, French SA, Hannan PJ, Murray DM. Predictors of weight gain in the Pound of Prevention study. Int J Obes Relat Metab Disord 2000; 24: 395-403. 
27 DiPietro L, Williamson DF, Caspersen CJ, Eaker E. The descriptive epidemiology of selected physical activities and body weight among adults trying to lose weight: the Behavioral Risk Factor Surveillance System survey, 1989. Int J Obes Relat Metab Disord 1993; 17: 69-76.

28 Fentem PH, Mockett SJ. Physical activity and body composition: what do the national surveys reveal? Int J Obes Relat Metab Disord 1998; 22(Suppl 2): S8-S14.

29 Delvaux K, Lysens R, Phillippaerts R, Thomis M, Vanreusel B, Claessens AL, Vanden Eynde B, Beunen G, Lefevre J. Associations between physical activity, nutritional practices and health-related anthropometry in Flemish males: a 5-year follow-up study. Int J Obes Relat Metab Disord 1999; 23: 12331241.

30 Dannenberg AL, Keller JB, Wilson PW, Castelli WP. Leisure-time physical activity in the Framingham Offspring Study: description, seasonal variation and risk factor correlates. Am J Epidemiol 1989; 129: $76-88$
31 Després JP, Prud'homme D, Pouliot MC, Tremblay A, Bouchard C. Estimation of deep abdominal adipose-tissue accumulation from simple anthropometric measurements in men. Am J Clin Nutr 1991; 54: 471-477.

32 Niedhammer I, Bugel I, Bonenfant S, Goldberg M, Leclerc A. Validity of self-reported weight and height in the French GAZEL cohort. Int I Obes Relat Metab Disord 2000; 24: 11111118.

33 Roberts RJ. Can self-reported data accurately describe the prevalence of overweight? Public Health 1995; 109: 275-284.

34 Seidell JC, Rissanen AM. Time trends in the worldwide prevalence of obesity. In: Bray GA, Bouchard C, James WPT (eds.) Handbook of Obesity. Marcel Dekker: New York; 1998. pp 79-91.

35 Manson JE, Hu FB, Rich-Edwards JW, Colditz GA, Stampfer MJ, Willett WC, Speizer FE, Hennekens $\mathrm{CH}$. A prospective study of walking as compared with vigorous exercise in the prevention of coronary heart disease in women. New Engl J Med 1999; 341: $650-658$. 